\title{
THE RENAISSANCE OF ENGLISH LEGAL HISTORY
}

\author{
D.J. IBBETSON*
}

ABSTRACT. John Baker's “English Law and the Renaissance” is perhaps the most significant paper in English legal history to appear in the Cambridge Law Journal. In many ways it was a response to, and development from, F. W. Maitland's Rede Lecture with the same title, published some 80 years previously. Baker's paper marks a punctuation in his study of English law under the early Tudors, a subject which he has made his own, culminating in his magisterial sixth volume of The Oxford History of the Laws of England. In addition, it marked a major break with the earlier orthodoxy that English law in this period was fundamentally distinct from the law which was developing on the European continent. The present paper explores both of these themes.

KEYWORDS: Legal History, Renaissance, Tudor England

\section{INTRODUCTION}

Early in May 1984, John Baker gave a Special Ford Lecture in the University of Oxford; a year later it appeared - together with the footnotes inevitably omitted from the lecture when it was delivered - in the Cambridge Law Journal. ${ }^{1}$ Its title, English Law and the Renaissance, was not simply a reference to its contents. Just over 80 years earlier, F.W. Maitland had delivered his justly famous Rede Lecture in Cambridge with exactly the same title. ${ }^{2}$ Baker's paper opened by saying that his purpose was not to give a reinterpretation of Maitland, but to examine the subject from a different standpoint. In doing so, he reflected major changes in our understanding of English, and continental European, legal history in the late fifteenth and early sixteenth centuries; so far as England is concerned, a good deal of this changed perspective stemmed

\footnotetext{
* Regius Professor of Civil Law, University of Cambridge. Address for Correspondence: Faculty of Law, 10 West Road, Cambridge CB3 9DZ. Email: dji22@cam.ac.uk.

1 J.H. Baker, "English Law and the Renaissance" [1985] C.L.J. 46 (reprinted in Sir John Baker, Collected Papers in English Legal History (Cambridge 2013) (hereafter Baker, CP), 1460 with lightly expanded footnotes). For Baker's later, expanded, thoughts on the subject, see his Oxford History of the Laws of England, vol. VI (Oxford 2003), 3-52.

2 F.W. Maitland, English Law and the Renaissance (Cambridge 1901). The best reprint is in Select Essays in Anglo-American Legal History, vol. 1 (Boston 1907), 168, which includes the very extensive footnotes. Page references are given to this edition.
} 
from the work of Baker himself over the previous ten years, notably in his Yorke Prize essay which had appeared as the introduction to his edition of the Reports of John Spelman published by the Selden Society; ${ }^{3}$ and work by him, and by others in his wake, over the following decades has consolidated this understanding.

The years around 1500 could be seen as a pivotal point in the Renaissance as Europe came out of the Middle Ages (though we would today not be so chronologically prescriptive). From a continental European point of view, law was a part of this Renaissance. From the last years of the fifteenth century there was a step-change in the use of the Roman law of the universities in legal practice, very visibly in Germany in the wake of the Reichskammergerichtsordnung of $1495 ; 4$ and from the first years of the sixteenth century we can date the rise of "legal humanism", marked by Guillaume Budé's Annotationes in Pandectas published in 1508. Whether English law was part of this legal Renaissance is problematic. For Maitland it seems it was not: humanism had its part to play in England, but the influx of Roman law was resisted. Only towards the end of his lecture, speaking of the later sixteenth century, does he grudgingly accept that "We were having a little Renaissance of our own", associated with the printing of medieval law books and the reshaping of that medieval law with the appearance of Coke's Reports. ${ }^{5}$ Eighty years later English legal historians were seeing the changes of the early sixteenth century rather differently: the rise of the various forms of action on the case, especially the contractual action of assumpsit; the growth of Chancery jurisdiction; the Statute of Uses; the printing of the year books and the cessation of the production of new volumes; the rise of a form of treatise literature, beginning with Littleton's Tenures; the reorientation of Common law procedure with a focus on post-verdict arguments. Undoubtedly, there had been some sort of renaissance of English law, and it was on this that Baker was concentrating. How, if at all, did that relate to the continental European legal Renaissance? How can it be understood on its own terms?

\section{FALSE TRAILS}

With a range of disparate things happening at about the same time, there is an inevitable temptation to clutch at straws and identify a single cause. One possibility would be a powerful individual or group of individuals, perhaps with a coherent self-interest. There was indeed such a powerful dynasty in the first half of the sixteenth century, associated with the Rooper family and

\footnotetext{
3 J.H. Baker (ed.), The Reports of Sir John Spelman, Selden Society vol. 94 (London 1977).

4 F. Wieacker, A History of Private Law in Europe, trans. T. Weir (Oxford 1995), 132-42.

5 Maitland, English Law and the Renaissance, 201.
} 
including Chief Justice Sir John Fyneux and Chancellor Sir Thomas More. Baker rightly rejects any theory which would link the legal Renaissance to the interest or avarice of a single group. ${ }^{6}$ It might be possible to construct an argument hanging the changes taking place a century later around the dominant personality of Chief Justice Sir Edward Coke, ${ }^{7}$ but the changes of the early sixteenth century were too diverse to make any such monocausal theory plausible.

A second red herring is the influence of legal humanism. Maitland had made something of this in 1901, but Baker rightly ignored it; and his later work suggests that he was right to do so. ${ }^{8}$ We can identify a current in continental, especially French, law schools which we know as legal humanism, and we can identify the influence of Budé, perhaps the earliest of the "legal humanists", on Christopher St. German, and we know that the first Regius Professor of Civil Law in Cambridge prepared for his new office by studying the new science, ${ }^{9}$ but there was no coherent movement of legal humanism in England. Nor would it be justifiable to make the leap from the humanism of Sir Thomas More to any current of so-called legal humanism. Even in continental Europe the undoubted trend of textcritical studies of the Roman sources, especially in the French universities, played little part in legal practice: Nemo jurista nisi Bartolista.

The third, and most important, red herring is the "Reception" of Roman law, which for Maitland was centre stage. In the orthodox historiography of his day, around 1500 the continental European legal systems were seen as adopting Roman law in place of their national or local customs, even if this adoption took on different aspects in different places. England did not experience any such reception, and for Maitland the question was, Why not? His answer was in the "tough law" taught in the Inns of Court. By 1984 the dominant European historiography had shifted. The "reception" of Roman law had come to be seen more in terms of the intellectualisation and professionalisation of legal practice. ${ }^{10}$ Trained lawyers should staff and appear in courts; and across continental Europe training meant studying in a university, and the law studied in the universities

\footnotetext{
${ }^{6}$ Baker, "English Law and the Renaissance", 49-50.

Essentially Maitland's "little Renaissance": English Law and the Renaissance, 201-02.

8 Baker, Oxford History of the Laws of England, VI, 15-18; see C.P. Rogers, "Humanism, History and the Common Law" (1985) 6 Journal of Legal History 129; D. Ibbetson, "Humanism and Law in Elizabethan England: The Annotations of Gabriel Harvey" in P. Du Plessis and J.W. Cairns (eds.), Reassessing Legal Humanism (Edinburgh 2016), 282.

9 P. Stein, Roman Law in European History (Cambridge 1999), 75-79; D. Ibbetson, "A House Built on Sand: Equity in Early Modern English Law" in E. Koops and W. Zwalve, Law and Equity: Approaches in Roman Law and Common Law (Leiden 2014), 55, with L. Maniscalco, Equity in Early Modern Legal Scholarship (Leiden 2020), showing that the common sixteenth-century equation of equity or aequitas with Aristotelian epieikeia can be traced back to Budé; Maitland, English Law and the Renaissance, 176.

${ }^{10}$ Wieacker, History of Private Law, 91-112: "Accordingly, if one is to see the Reception in its full historical significance it is better to concentrate less on the adoption of the actual rules of the ius commune and more on the main process of development, namely on the intellectualization of German law and lawyers" (at 95, emphasis in original).
} 
was Roman law. ${ }^{11}$ By applying Roman law, as understood in the early modern universities, disputes could be resolved by a fixed, written law rather than by uncertain and malleable custom, giving rise to a more certain, objective justice. Against this background, Baker sees the irrelevance of Maitland's primary question. The Inns of Court were as central for him as for Maitland, ${ }^{12}$ but not so much as a gatekeeper against the supposed risk of a reception of Roman law; rather simpler than that, English law was already professionalised, staffed and operated by learned lawyers, lawyers who had learned their law not in universities but in the Inns of Court and later through legal practice.

\section{Doctrine, JurisPrudence the Growth of Printing}

By abandoning, or at least heavily downplaying, Maitland's quest to understand why England did not experience a "reception" of Roman law, Baker could bring the legal developments in England in this crucial period into the mainstream of European legal development at the time. Of course, in point of substance, English law and the law of most of the European continent were very different; the dominant role of Roman law on the continent ensured that. There is very considerable cross-citation of material across the various continental jurisdictions, but never, so far as we know, any reference to English cases in France, Italy or the like; Riccio's collection of decisions from all around Europe, published in 1619 contains references to around 250 volumes of reports, none of which is English. ${ }^{13}$ The reverse is true in England; outside the ecclesiastical courts and the Admiralty, which applied the civil law, English lawyers paid no heed to continental decisions. ${ }^{14}$ The difference between England and continental Europe lay in which previous decisions were used but not in the use of previous decisions in argument.

Remove the reception/no-reception distinction between continental England and Europe, the way was open for a more nuanced analysis of the use of Roman law in sixteenth-century English law. Baker himself, for example, has identified a Roman-inspired set of glosses in some copies of Littleton's Tenures, suggesting that some lawyers around 1600 must have found Roman law of use in understanding the English law of real property. ${ }^{15}$ William West, a Yorkshire attorney, plagiarised work of the German Hermann Vulteius in his Second Part of the Symboleography in 1594; and this seems to have been a route for Romanised ideas to reach

11 Baker, "English Law and the Renaissance", 50-51.

12 Ibid., at 50: "Here, by a different route, we join Maitland."

13 G. Riccio, Collectanea Decisionum (Rome 1619).

14 An exception proving the rule is Rolle Abridgment, Nusans, F2, referring to Papon, Arrêts, Droits Seigneuriaux, 32 and De Servitutes, 11.

15 "Roman Law at the Third University of England" (2002) 55 Current Legal Problems 123 (Baker, CP, 367). 
impeccably English lawyers. ${ }^{16}$ Francis Bacon freely borrowed Roman texts alongside English materials in his Maxims of the Law. ${ }^{17}$ Well before this, Christopher Saint German had used Aristotelian ideas channelled through the Swiss humanist Guillaume Budé to explain the "equity" of the English Court of Chancery, an understanding it took more than a century to grub out. ${ }^{18}$ Nor should this surprise us. Why should English lawyers not borrow ideas from elsewhere if they seemed useful?

More importantly, it clears the way to removing the rather unthinking assumption that English law was from the start a system of case law based on judicial decisions, contrasting with continental law which was derived from, or centred round, the scientific study of Roman law, the French distinction between jurisprudence and doctrine, something which up to the late twentieth century had also bedevilled attempts to compare English and continental European legal history. ${ }^{19}$ It was all too easy for those of Maitland's generation and after who wrote about legal history in England to give primacy to decided cases. Most of them were trained as lawyers and either taught or practised law (or indeed, as Maitland himself, both). Textbooks could, in theory, only be cited in support of a proposition of law after the death of the author; the textbook was supposed to reflect what the cases had decided, visible on every page by the copious case-law authorities printed in the footnotes. It was much the same in reverse for continental European legal historians, thinking substantially in terms of the modern lawyer's primary concern with legal science and reading it back into the early modern period. The heart of Baker's lecture was taken up with showing that around 1500 there was no such hard division between England and the continent. ${ }^{20}$

Case law had, undoubtedly, its part to play in early Tudor England. So obvious was this to Maitland that he could see the cessation of the year books after 1535 as a threat to the Common law. ${ }^{21}$ By the 1980 s it was known that manuscript law reports continued to be produced in some number across this boundary ${ }^{22}$ - no one has done more than Baker has to

16 J. Mansky, "Edward Coke, William West, and the Law of Libel", Journal of Legal History (forthcoming in 2021), identifying West as the source of Coke's Roman law in his report of the Case de Libellis Famosis (1605) 5 Co. Rep. 125.

17 F. Bacon, Maximes of the Law (London 1596). Rule 11, for example, is identical to D.50.17.8.

18 Stein, Roman Law in European History, 75-79; Ibbetson, "A House Built on Sand", 55, with Maniscalco, Equity in Early Modern Legal Scholarship, showing that the common sixteenth-century equation of equity or aequitas with Aristotelian epieikeia can be traced back to Budé; Maitland, English Law and the Renaissance, 176.

19 Baker, "English Law and the Renaissance", 51. At note 13 Baker refers to a then projected series of Comparative Studies in Continental and Anglo-American Legal History funded by the Gerda Henkel Stiftung. This series, of course including contributions by Baker himself, has proved invaluable in breaking down the methodological barriers between English and American legal historians and their continental counterparts.

20 Ibid., at 51-56.

21 Maitland, English Law and the Renaissance, 192, especially with footnote 49: "The fact seems clear that the ancient practice of law reporting passed through a grave crisis in the sixteenth century."

22 Baker, Reports of Sir John Spelman, 170-76. 
demonstrate this conclusively, through his editions of series of Henrician reports for the Selden Society - and it was becoming abundantly clear that the end of the canon of printed year books was more than anything a product of the economics of the printing trade. ${ }^{23}$ But the contrast with continental Europe was more apparent than real. By 1500 lawyers in France and Italy were clearly taking an interest in decided cases; Baker traced this back to the reporting of decisions of the Roman Rota in the middle of the fourteenth century, moving into the secular context through the Grenoble decisions of Guy Pape in the middle of the fifteenth century, printed in $1490 . .^{24}$ The existence of such continental reports was well known to scholars in Germany and elsewhere ${ }^{25}$ and J.P. Dawson had referred to them in English in the 1960s, ${ }^{26}$ but this had hardly been picked up by the mainstream of anglophone legal historians before Baker. ${ }^{27}$

The reverse was the case for doctrine. Contrary to the unthinking orthodoxy, Baker stressed that the lawyer of the early sixteenth century put as much weight on opinions expressed in the Inns of Court as on what had been decided in Westminster Hall. ${ }^{28}$ His later work, especially The Law's Two Bodies, has built on this. ${ }^{29}$ Law was as much, perhaps more, the professional consensus of lawyers as it was something sent down from on high in judicial decisions. Moots and readings in the Inns of Courts, especially the latter, are quite as relevant as sources of the legal history of the period as reports of cases. Before Baker they were known but for the most part unstudied. Until the publication of his magisterial catalogue of readings they were for the most part undiscoverable. ${ }^{30} \mathrm{He}$ was soon to set a $\mathrm{PhD}$ student on a study of readings on the Statute of Wills of $1540 . .^{31}$

From these substantially common beginnings we may see the divergence of English law from that of the European continent in the sixteenth and seventeenth centuries. It was not simply because, as Regius Professor Sir Thomas Smith wrote in the middle of the century, unlike in England in

${ }^{23}$ Baker, Oxford History of the Laws of England, VI, 7 (referring to earlier writings of A.F. Pollard and T.F. T. Plucknett)

24 Baker, "English Law and the Renaissance", 54-56.

25 See the various chapters in H. Coing, Handbuch der Quellen und Literatur der Neureren Europäischen Privatrechtsgeschichte, vol. II/2 (Munich 1976).

26 J.P. Dawson, Oracles of the Law (Ann Arbor 1968).

27 Anecdotally, my own first realisation of this was in the 1980s, when Dr. Baker, as I think he then was, invited a group to his rooms for refreshment after a working group's dinner. He plucked off his shelf a copy of a continental collection of decisiones to show us that the continentals had reports too.

${ }^{28}$ Baker, "English Law and the Renaissance", 51-53.

29 J.H. Baker, The Law's Two Bodies: Some Evidential Problems in English Legal History (Oxford 2001); prefigured in "The Inns of Court and Legal Doctrine" in T.M. Charles-Edwards (ed.), Lawyers and Laymen: Studies in the History of the Law presented to Professor Dafydd Jenkins (Cardiff 1986), 274 (Baker, $C P, 352$ ).

30 J.H. Baker, Readers and Readings in the Inns of Court and Chancery, Selden Society Supplementary Series vol. 13 (London 2000).

31 M.C. Mirow, Readings on Wills in the Inns of Court 1552-1631 (University of Cambridge PhD, 1992). See M.C. Mirow, "The Ascent of the Readings: Some Evidence from Readings on Wills" in J. Bush and A. Wijffels (eds.), Learning the Law: Teaching and Transmission of English Law, 1150-1900 (London 1999), 227. 
France, Italy, Spain and Germany they followed the civil law of the Romans compiled by Justinian. ${ }^{32}$ The systems differed from each other because of the role their own customary law and their own judicial practice played, but Roman law was a "secure point of reference" 33 for them as it was not for the Common lawyer. It was, we may suspect, the printing press that magnified this difference between England and continental Europe and drove a wedge between the different traditions.

So far as doctrine was concerned, printing had a differential effect. In England, the equal weight attaching to decisions and opinions expressed in the Inns of Court was very much a phenomenon we should associate primarily with the oral culture which prevailed before the printing revolution. The printers did print treatise literature, but in the first half of the sixteenth century it was skewed somewhat in the direction of texts from the thirteenth and fourteenth centuries. The grant of a monopoly of the printing of law books (except statutes) to Richard Tottell in 1555 (renewed in 1559) ${ }^{34}$ meant that there was no competitive pressure to produce new literature, and even when new books were printed they were substantially descriptive, not to say pedestrian. ${ }^{35} \mathrm{We}$ would be hard pressed to find any treatise literature in the sixteenth century which we could call scientific. Such treatise literature as there was in print took its place alongside the reported cases, but by the early seventeenth century the dominant authorities in legal reasoning were judicial precedents; ${ }^{36}$ case law prevailed over doctrine. The contrast with continental Europe could not be more stark. There was an enormous outpouring of commentaries on particular aspects of Roman law, as well as the printing of massive commentaries by the glossators and post-glossators written from the twelfth century onwards. Any of them could be cited anywhere that Roman law was relevant, adding to the overwhelming mass of source material. But this did not really matter. These commentaries, general or specific, were no more than interpretations of the underlying texts of Roman law, added to by the mass of decisiones literature. Where English law was reducing its citation of, and apparent reliance on, discursive or interpretative literature, continental legal systems were increasing it.

So far as reports are concerned, in England the printing of the year books brought about a textualisation of case law. The canon of year books in print by the 1540s made possible the framing of arguments on a precisely worded legal text, and moreover one which was more or less thoroughly

32 T. Smith, De Republica Anglorum (1583), 118 (L. Alston. (ed.), (Cambridge 1906), 142).

33 The term is taken from M. Bellomo, The Common Legal Past of Europe, trans. L.G. Cochrane (Washington 1995), 32.

34 Baker, Oxford History of the Laws of England, VI, 497-99.

35 Ibid., at 499, naming Staunford's Les Plees del Coron (London 1557) as an exception.

36 D. Ibbetson, "Authority and Precedent" in M. Godfrey (ed.), Law and Authority in British Legal History, 1200-1900 (Cambridge 2016), 60. 
searchable through the subject headings in Fitzherbert's Graunde Abridgment; before that, the framing of unorthodox or heterodox arguments would have been next to impossible. Contrary to Maitland's suggestion that the cessation of the year book tradition was a threat to the Common law, it may in truth have been the reverse. The formation of a canon of yearbooks rooted the Common law of the mid-sixteenth century in the legal practice of the fourteenth and fifteenth. As Baker points out, the failure to print new year books in the sixteenth century did not reflect the ending of law reporting, which went on apace in manuscript. It was a function of the economics of the printing trade, which required a guaranteed minimum sale in order to be profitable; and the grant of the monopoly of legal printing to Richard Tottell meant that there was no pressure which might have brought about the taking of risks. There is no evidence that Tottell was seeking out new reports to print. By 1600 there were only three further English printed texts of reports: Plowden $(1571,1578)$, Dyer (1585) and the first volume of Coke (1600), and all these were printed on the initiative of the reporter or (in the case of Dyer) his family. Moreover, before the appearance of Coke's Reports there may not even have been an appetite for new reports on the part of a large enough number of lawyers to make the printing of new reports commercially viable. There was an increase in the pace of printing after 1600, particularly with the eleven volumes of Coke's Reports which were published in his lifetime, but, crucially, the total number of volumes in print by 1630 was still not unmanageable, allowing English lawyers to frame their arguments around printed texts without always coming up against conflicting authorities. ${ }^{37}$ Moreover, a further limit on the availability of source material was brought about by a system of licensing the printing of reports, which was formalised in $1637 .{ }^{38}$

Continental Europe was different. Because Roman law lay at the base of the separate systems decisiones from one place could be freely cited in argument in another, just as much as commentaries on Roman law could. ${ }^{39}$ Except where they were based on local custom or practice, individual decisions showed the way in which Roman law principles could be applied to sixteenth-century problems. Some decisions might have binding normative force in their region, but only if they had been reached, perhaps with some additional formality, by a sovereign court with legislative or quasi-legislative power; 40 beyond that, they were not formally binding

37 For the increasing primacy of the written text, see I.S. Williams, "'He Creditted More the Printed Booke': Common Lawyers' Receptivity to Print, c. 1550-1640" (2010) 28 Law and History Review 39.

38 J.H. Baker, "English Law Books and Legal Publishing" in J. Barnard and D.F. McKenzie (eds.), The Cambridge History of the Book in Britain, Volume IV: 1557-1695 (Cambridge 2002), 474, 492-93 (Baker, CP, 637). There had been an earlier decree in 1586, but it seems that this was not enforced.

39 D. Ibbetson, Common Law and Ius Commune (London 2001), Selden Society Lecture, 18-19.

40 Ibbetson, "Authority and Precedent", 66-69. At the base of this was Matthaeus de Afflictis, Decisiones (1499), Decisio 96 no. 11, 169 no. 9, 383 no. 8. The decisions of the Sacrum Consilium of Naples (which Afflictis was reporting) had been given legislative force by statute. 
and so might be as relevant hundreds of miles away as they were in the court in which they were decided. The economics of printing operated differently from the way in which they operated in England. The potential market for any volume was far larger than for any similar volume in England, as they were traded, perhaps haphazardly, across Europe (and indeed via Spain into South America). The greater market for continental decisiones encouraged greater production, and with a stronger expectation of sales and no single monopolist the economic pressure which affected English legal printing was far less significant. This created something of a crisis in continental Europe, as the number of volumes became utterly overwhelming. By the end of the seventeenth century some 700 volumes of decisiones had been printed; ${ }^{41}$ in Italy alone by 1600 there more than 30 volumes compared with the three sixteenth-century texts in print in England. ${ }^{42}$ Where the rise in the number of printed texts of reports in England served to blot out the use of manuscript reports in forensic argument, in continental Europe the whole edifice toppled, coalescing or re-coalescing into national systems. ${ }^{43}$

The continental parallel may cause us to reassess the English evidence by asking a fundamental question: What is a report? It is easy to slip into the assumption that it is a memorial of the facts of a case, perhaps the arguments of counsel, the opinions of the judges and the result of the case; the opinions of the reporter are irrelevant except perhaps for an occasional sed quaere. If we look at French reports of the sixteenth century, typified by those of Nicolas Bohier, ${ }^{44}$ they are in what we should think of as the classic "decisiones" form: a question in Latin, subdivided into separate points each of which is analysed largely (though not exclusively) through texts of the Roman law and canon law and their later commentators, commonly not giving the date or the names of the parties. Since Bohier was President of the Bordeaux court it is likely that he was privy to the court's reasons, or at least his own, but none the less the decisiones read like short essays answering specific questions. A major shift of focus occurred in the middle of the century. The collection of Jean Papon no longer bears the title "Decisiones"; rather it is described as "Arrêts", judgments. ${ }^{45}$ They are not written in Latin, but French. Their whole focus is the judgment itself; they are not structured as short essays answering a specific question.

41 A. Fontana, Amphitheatrum Legale (1688), part 3, cols. 358-80.

${ }^{42} \mathrm{M}$. Ascheri in Coing, Handbuch der Quellen und Literatur der Neureren Europäischen Privatrechtsgeschichte, 1179-82.

43 I have suggested (following Coke) that it was this top-heaviness that provided a strong argument against the adoption of the civil law in England after the union of the crowns of England and Scotland: "English Law and the European Ius Commune 1450-1650" (2005-6) 8 Cambridge Yearbook of European Legal Studies $115,128-31$.

${ }^{44}$ N. Boerii Decisiones supremi senatu Burdegalenses (Lyons 1544). For Bohier and his work, see J. Hepburn, "A Lawyer and His Sources: Nicolas Bohier and Legal Practice in Sixteenth-century France" in Du Plessis and Cairns, Reassessing Legal Humanism, 244.

45 J. Papon, Recueil d'Arrests Notables des Cours Souveraines de France (Lyons 1556). 
They have a very wide chronological range, and were hence clearly not the product of Papon's own experience; and they contain very little in the way of reasons. ${ }^{46}$ The same is true of the slightly later collection of Georges Louet, ${ }^{47}$ though he gave greater weight to the arguments of the advocates than had Papon. The contrast between decisiones and arrêts is very well brought out in Jorge de Cabedo's two Portuguese collections, explictly modelled on the French experience. Here we find a division between decisiones and arresta, described as sententia supremi senatus. ${ }^{48}$ The former are in Latin and contain full reasons, structured analytically, largely based on Roman law and its later interpretation as well as the Portuguese Ordinationes and some decisiones. The latter are brief, in Portuguese and substantially unmotivated, though many of those in the second collection end with a statement of the "ratio". Clearly the decisiones and arresta are different. It seems that the latter are undistilled statements of judicial decisions, while the reasons in the former may be as much the work of the reporter as reflections of what the judges said or wrote.

Does this help us understand the English-law contrast between Plowden's Commentaries and Dyer's Reports on the one hand and Coke's Reports on the other? We know that Coke was criticised by Ellesmere for massaging his Reports ${ }^{49}$ and careful study of the relationship between his own manuscript report of a case and his printed version can reveal just how this massaging occurred. ${ }^{50}$ Ellesmere was perhaps not being entirely fair when he lambasted Coke for this; it may be that Coke was just following (or experimenting with) a different model, one in which the reporter was expected to be shaping the reasons, perhaps even departing from any reasons given by the judges.

\section{External AND INTERnAl Drivers For Legal CHANGE}

Maitland's third R, alongside Renaissance and Reception, was Reformation. At least sub-textually, for him the division between Protestantism and Roman Catholicism provided a major part of the background to English law's changes in the sixteenth century. The early protestant reformer John Wycliffe had argued that English law should be taught in

46 French courts' decisions were formally unreasoned: S. Dauchy and V. Demars-Sion, "La non-motivation des décisions judiciaires dans l'ancien droit: principe ou usage" (2004) 82 Revue historique de droit français et étranger 223.

47 G. Louet, Recueil d'aucuns Notables Arrests donnez en la Cour de Parlement de Paris (Paris 1602).

48 J. de Cabedo, Practicarum Observationum sive Decisionum Supremi Senatus Lusitaniae (Lisbon 16021604); I have used the edition printed in Antwerp in 1635, in which the arresta begin in part 1, 195, and part 2,175 . In the prefatory note to the arresta in part 2, Cabedo refers explicitly to the French model of reporting arrêts. See further J.-M. Scholz in Coing, Handbuch der Quellen und Literatur der Neureren Europäischen Privatrechtsgeschichte, 1330-33.

49 "The Lord Chancellor Egertons Observacions upon ye Lord Cookes Reportes" in L. Knafla, Law and Politics in Jacobean England (Cambridge 1977), 297.

50 This will become abundantly clear when Professor Baker's Selden Society edition of cases from Coke's Reports is published. 
English universities, not Roman law. ${ }^{51}$ By contrast, the future Cardinal Reginald Pole argued for the adoption of Roman law. ${ }^{52}$ After the reformation England stuttered away from Roman catholicism, and at the same time its first Regius Professor of Civil Law in Cambridge, Thomas Smith, and the first reputable Regius Professor of Civil Law in Oxford, Alberico Gentili, were good protestants. ${ }^{53}$ Asking why English law had experienced no reception of Roman law it was all too easy to hypothesise a link between Roman Catholicism and Roman law, though Maitland himself recognised that it was not so simple.

More theoretically, In Maitland's time it was not difficult to slip into a supposition that major legal change occurred in response to social forces external to the law, though no serious legal historian - certainly not Maitland - would assert that this was the whole story. By 1984, the balance had shifted. Milsom's Historical Foundations of the Common Law had gone into its second edition, and Cambridge legal historians were being taught a model of legal historical development which was substantially internal. Baker steered a very careful middle course, accepting that the external forces at work in the early sixteenth century could hardly be ignored, but rightly counselling that seeking to identify the causal links between external forces and legal change is "fraught with difficulties". 54 The legislation which brought about the break with Rome around 1530 "had little direct effect on everyday law",55 however much it inevitably formed part of the backdrop to the major legal changes which were occurring. Precise chronology is crucial. "There might be some perverse pleasure to be derived from linking the origins of the modern law of contract to Queen Katharine's inability to produce a son; but that possibility has been laid to rest by research which shows that the graph is illusory."56 Legislation might be easier to explain as a response to external pressures, but even the Statute of Uses 1536, whose immediate cause can be seen as the need for Henry VIII to raise money independent of parliamentary taxation, can only be properly understood if we take into account the assimilation of the powers of the cestui que use to those of the freeholder over the previous half century.

Baker's basic analyses of the Statute of Uses and the action of assumpsit remain largely uncontroversial, but later work has filled in more detail and enabled us to have a more nuanced picture of their development. Greater study of the plea rolls of the Common Pleas and of the readings has cast more light on the ways in which the rights of the cestui que use were

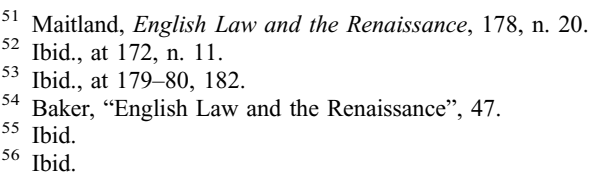


approximated to those of the freeholder after the statute of $1484 ;{ }^{57}$ work on the Chancery records has brought to the surface knowledge of the ways in which uses were being framed at about the time of the Statute of Uses; ${ }^{58}$ and we understand more about how the Crown achieved its fiscal objectives after the Statute of Wills brought about a partial volte-face from the Statute of Uses in $1540 .{ }^{59}$ A sharper understanding of the early history of assumpsit has developed, ${ }^{60}$ but it cannot be said that we have reached finality. As Baker himself wrote in the Cambridge Law Journal earlier this year, a propos of a recent discovery he had made in the plea rolls, "The textbooks will have to be adjusted". ${ }^{61}$ Looking at sources from the later sixteenth century, we have begun to investigate commercial developments against the background of what was then the well-established action of assumpsit. ${ }^{62}$ Much of this builds upon Baker's work; and when we are examining these more specific contexts the discovery of the interplay between external and internal factors is not quite as "fraught" as trying to link general legal developments to broader historical currents. The main problem, always, is to get a very accurate fix on chronology so that legal responses to events outside the law can be evaluated; but even where the chronology can be pinned down influence can be next to impossible to establish firmly. Baker, for example, is right to be critical of any facile suggestion that the Pilgrimage of Grace "caused" the Statute of Wills; his own far more careful and detailed study of the immediate legal antecedents of the Statute furnishes us with a more persuasive story. ${ }^{63}$

\section{JUDICIAL LAW-MAKING}

The final section of Baker's lecture as published in the Cambridge Law Journal bears the heading "Judicial Law Making". ${ }^{64}$ This has two aspects: the development of this in England; and any parallel with continental Europe.

A good case could be made for saying that the rise of judicial lawmaking was the most significant of all the changes that marked sixteenthcentury English law, although as Baker himself says, "[T]here was never a time when the common law was not in some sense 'case-law', the

${ }_{57}$ Baker, Oxford History of the Laws of England, VI, 655-60.

58 N.G. Jones, "Trusts Litigation in Chancery after the Statute of Uses: The First Fifty Years" in M. Dyson and D. Ibbetson (eds.), Law and Legal Process (Cambridge 2013), 103.

59 N.G. Jones, "The Influence of Revenue Considerations upon the Remedial Practice of Chancery in Trust Cases, 1536-1660" in C.W. Brooks and M. Lobban (eds.), Communities and Courts in Britain, 1150-1900 (London 1997), 99.

${ }^{60}$ Baker, Oxford History of the Laws of England, VI, 839-74; D. Ibbetson, "Consideration and the Theory of Contract" in J. Barton (ed.), Towards a General Law of Contract (Berlin 1998), 67.

61 J.H. Baker, "Indebitatus Assumpsit in 1447" [2021] C.L.J. 39, 41.

${ }^{62}$ For example G. Rossi, Insurance in Elizabethan England: The London Code (Cambridge 2016).

63 Baker, Oxford History of the Laws of England, VI, 679-83.

${ }^{64}$ Baker, "English Law and the Renaissance", 58-61. 
outcome of solutions found in real cases." 65 But the "in some sense" bears a considerable weight here, and - as Baker himself has shown more than anybody - the changes of the sixteenth century brought about a major transformation in the nature of case law. There are a number of dimensions to this. It may be that around 1500 there was a changed perception of law, shared between England and continental Europe, according to which disputes should be resolved according to determinate rules, a rise of legal positivism. ${ }^{66}$ No longer would it be seen as ideal to leave to the jury a very general issue - Does the defendant owe the plaintiff $£ 10$ as the plaintiff says? - in effect throwing it to them to decide in what circumstances money was owed. If dispute resolution was to be properly rule-based, then it be for the trained judges, judges who knew or who could discover the law, to say what those rules were and to apply them. This coincided with the enormous increase in post-verdict motions in the early part of the sixteenth century, and the more general acceptability of special verdicts by the end of the reign of Elizabeth. ${ }^{67}$ Equally, it is reflected in more precise canons of contractual interpretation than would have been found before the Tudor transformation. ${ }^{68}$ Secondly, the increased use of actions on the case, in which the plaintiff's case was spelled out in some detail, made it possible to raise more sharply focused objections to the way in which actions had been framed. This was especially the case with the post-verdict motion in arrest of judgment after a verdict had been given for the plaintiff. It was through such motions, for example, that the detailed contours of the doctrine of consideration in assumpsit were mapped. ${ }^{69}$ Thirdly, there was a move from oral tentative pleading, the characteristic of the medieval Common law, to the enrolment of paper pleadings, with no pre-verdict judicial involvement; no doubt this was facilitated by the falling cost of paper, though the details of the shifts which occurred are very hard to track. ${ }^{70}$ It was this, more than anything, which opened the way for the massive rise in post-verdict motions: if the pleadings had been settled without judicial involvement, it was only after the trial at nisi prius that legal argument about the sufficiency of the plaintiff's claim or the defendant's pleaded defence could be raised. The result of this was, whether they liked it or not, that the judges had little choice but to decide the case one way or another, unless they were to adjourn from term to term while they tried

\footnotetext{
65 J. Baker, Introduction to English Legal History, 5th ed. (Oxford 2019), 207.

${ }^{66}$ Ibid., at 209.

${ }^{67}$ Baker, Oxford History of the Laws of England, VI, 400-03.

68 J. McCunn, "Revolutions in Contractual Interpretation: The Historical Perspective" in S. Worthington, A. Robinson and G. Virgo, (eds.), Revolution and Evolution in Private Law (Oxford 2018), 141.

${ }^{69}$ Ibbetson, "Consideration and the Theory of Contract".

70 R. Edvinsson and J. Soderberg, "Prices and the Growth of the Knowledge Economy in Sweden and Western Europe before the Industrial Revolution" (2011) 59 Scandinavian Economic History Review 250, 254-56, based on the database of G. Clark; Baker, Oxford History of the Laws of England, VI, $335-44$.
} 
to make up their minds - although, as Slade's Case shows, they were willing to do this if need be. There was far greater scope for judicial argument than there had been in the world of tentative pleading, and for judicial argument to crystallise into legal rules.

There is no doubt that medieval judges had acted more or less consistently, but the greater emphasis on judicial decision-making in the sixteenth century imparted a new flavour to this. Judicial statements were a species of authorities, in the classical sense that they could be used as evidence in subsequent argument, and the dialectical maxim that an expert in his art ought to be believed meant that rather greater weight ought to be accorded to judicial decisions than to counsel's arguments. In the latter part of the sixteenth century there was something of an assimilation of authority and precedent, and especially in the years after 1600 authoritative weight was attached in particular to judicial precedent. The balance was now shifted towards what was to become the characteristic English mode of case-law reasoning. ${ }^{71}$

The conditions which made this shift possible in England were equally present in continental Europe. There were published collections of reported decisions from the end of the fifteenth century, proliferating in the sixteenth. ${ }^{72}$ The classical argument from authority was well described in works of legal dialectic, and by the middle of the sixteenth century the argument from authority based on Cicero was being assimilated to the argument from precedent based on Quintilian; ${ }^{73}$ it is likely, in fact, that the English development of the later sixteenth century was triggered by this continental literature. ${ }^{74}$ The maxim that an expert in his art ought to be believed was as much a commonplace in continental Europe as in England. None the less, so far as we understand it, the shift towards according very strong weight to judicial precedent did not occur, or at least did not occur in the same way. There were a number of reasons for this divergence, largely stemming from the place of Roman law in continental Europe. A principle of Roman law, based on a text in Justinian's Codex, was that one should judge by the laws rather than by precedents (legibus non exemplis) ${ }^{75}$ ensuring that the proper interpretation of the texts had greater force than any individual decision about its interpretation. Roman law was heavily studied in the universities, so that the maxim that an expert in his art ought to be believed privileged the views of the professors of Roman law over the views of less expert judges. As well, there was the problem noted above that the sheer volume of literature, both decisiones and commentaries, made it very difficult to give determinative weight to anything

\footnotetext{
Ibbetson, "Authority and Precedent".

Baker, "English Law and the Renaissance", 54-56.

3 N. Everaerts, Loci Argumentorum Legales (Lyons 1564), 581, 582: "Haec argumentatio ab autoritate seu exemplo maiorum, vel si malis a praeiudiciis seu pronuntiatis" (emphasis added).

74 S. Vogenauer, Die Auslegung von Gesetzen in England und auf dem Kontinent (Tübingen 2001), 766.

75 C. 7.45 .13 .
} 
other than the formally binding rules extracted from the Roman jurists or the sovereign legislation in individual systems. Some decisions of superior courts did generate rules binding in an individual system, but only when the court reaching the decision had a legislative status, for example because it was the court of the sovereign him- or herself. ${ }^{76}$ As the volume of material became too unwieldy in the seventeenth century there was something of a collapse into national systems; but the rules of these national systems were not generated by judicial decisions. ${ }^{77}$

\section{A Personal Reflection}

Those of us who write articles, and those of us who edit journals, may like to think that articles can change the world. Rarely, if ever at all, do they do so. But an article can constitute a significant punctuation mark in the totality of a scholar's output. "English Law and the Renaissance" is such an article. Focusing as it does on the years around 1500, it marks a mid-point between Baker's Introduction to The Reports of Sir John Spelman, appearing in 1977, and his magisterial sixth volume of the Oxford History of the Laws of England covering the period 1483-1558 which appeared in 2003. In any context but a volume like the present it would be nothing short of hubristic to write about this period. Baker has already done it far better.

Baker's influence on the study of English legal history has been profound, so much so that anyone today who approaches the subject through his Introduction to English Legal History can hardly imagine what it was like before the 1970s. Most importantly, perhaps, he has pioneered the large-scale use of manuscripts - plea rolls, reports, readings - in the study of early modern legal history. ${ }^{78} \mathrm{He}$ was not the first to see that the manuscripts might tell us more than the printed sources, ${ }^{79}$ but he took their use to an entirely new level. His students, and his students' students, working on the law of the sixteenth century routinely use manuscript and archival material; and they are not alone.

What Maitland did for the thirteenth century, Baker has done for the sixteenth. And, like Maitland, he has served future legal historians through his editions of the texts of manuscript law reports of the period. Further than this, his catalogues of manuscripts have opened doors which were formerly firmly closed; his Catalogue of English Legal Manuscripts in Cambridge

76 Ibbetson, "Authority and Precedent", 66-69. At the base of this was Matthaeus de Afflictis, Decisiones (1499), Decisio 96 no. 11,169 no. 9, 383 no. 8. The decisions of the Sacrum Consilium of Naples (which Afflictis was reporting) had been given legislative force by statute.

77 See now G. Rossi (ed.), Authorities in Early Modern Courts (Edinburgh 2021).

78 Beginning with "New Light on Slade's Case" [1971] C.L.J. 51, 213 (Baker, CP, 1129), which cast much new light on a topic which was already well illuminated.

79 For a very early example, see J.H. Beale, "Southcott v Bennett" (1899) 13 Harvard Law Review 43. More recent examples were E.W. Ives, "The Genesis of the Statute of Uses" (1967) 87 English Historical Review 673 and A.W.B. Simpson, History of the Common Law of Contract (Oxford 1975), 623-40. 
University Library, ${ }^{80}$ in particular, is a work of prodigious scholarship with cross-references to materials in well over one hundred different collections around the world.

Yet there is one trail which he laid in "English Law and the Renaissance" which he has not (yet?) followed through to its end. In one of the more memorable passages in his Rede Lecture Maitland wrote: "We have all of us been nationalists of late. Cosmopolitanism can afford to wait its turn." 81 Baker laid the foundations for this cosmopolitanism, enabling us to see how the English legal renaissance of the sixteenth century and the continental legal renaissance of the sixteenth century might be - and might not be - parts of the same story. The sixteenth century was the crucial period in which English law, methodologically, split off from the direction of travel of continental European legal systems, so the similarities and differences at this time are of central importance. It may, or may not, be that the world will turn full circle and we will come back to the supposition of Maitland's time that this split was at its core the result of the different parts played by Roman law. When this history comes to be written, Baker's "English Law and the Renaissance" will have had its place in the unfolding of that story.

\footnotetext{
80 With J. Ringrose (Woodbridge 1996).

81 Maitland, English Law and the Renaissance, 175.
} 